\title{
Post-Acquisition Performance of Emerging Market Firms: A Multi-Dimensional Analysis of Acquisitions in India ${ }^{\dagger}$
}

\author{
Arindam Das \\ T A Pai Management Institute, Manipal Academy of Higher Education, Manipal 576104, India; \\ arindam.iift@gmail.com \\ + An earlier version of the paper was presented at a conference on Emerging Themes in Strategy, held at \\ Management Development Institute, Gurgaon, India in 2016.
}

check for

updates

Citation: Das, Arindam. 2021

Post-Acquisition Performance of

Emerging Market Firms: A

Multi-Dimensional Analysis of

Acquisitions in India. Journal of Risk

and Financial Management 14: 567.

https://doi.org/10.3390/jrfm14120567

Academic Editor: Anastasios

G. Malliaris

Received: 2 August 2021

Accepted: 9 November 2021

Published: 24 November 2021

Publisher's Note: MDPI stays neutral with regard to jurisdictional claims in published maps and institutional affiliations.

Copyright: (C) 2021 by the author. Licensee MDPI, Basel, Switzerland. This article is an open access article distributed under the terms and conditions of the Creative Commons Attribution (CC BY) license (https:/ creativecommons.org/licenses/by/ $4.0 /)$

\begin{abstract}
M\&A performance is a multifaceted, compound construct with no overarching factor that captures all different dimensions. This paper examines the concept of acquisition performance and proposes a model that links firm-level factors and transaction parameters with firms' short-term and long-term performance, extending to financial-, market- and innovation measures. Building on past empirical studies on the influence of various factors on M\&A performance, a multi-dimensional structural equation model has been developed and it has been tested with a dataset on acquisitions in the Indian technology sector over a period of ten years. The results suggest that: (a) smaller acquirers with higher book value and leveraged firms demonstrate better long-term performance; (b) contrary to established understanding, short-term market returns are not influenced by deal parameters; (c) majority stake purchases show relatively lesser gains-suggesting the possible presence of postacquisition integration issues and, (d) acquirers with high intangible assets continue to do well on innovation performance post-acquisition. By indicating situations and conditions under which an acquisition would potentially lead to a performance gain for the acquirer, these results provide significant insight to practitioners pursuing M\&As for growth opportunities.
\end{abstract}

Keywords: mergers and acquisitions; firm performance; structural equation modeling; emerging markets

\section{Introduction}

Mergers and acquisitions (M\&As) have increased in India and worldwide in recent decades: since 2000, more than 790,000 transactions have been announced worldwide with a known total value of more than USD 57 trillion (IMAA 2021). According to the statistics published by the Institute for Mergers, Acquisitions and Alliances (IMAA), with a total transaction value of USD 3.8 trillion in 2017, global M\&A deal value peaked at an unbelievable level of USD 10 billion a day. However, the question on how M\&As create value for stakeholders has not found a definitive answer yet. Findings from academic research have been inconsistent at best, primarily due to the fact that each M\&A tends to be unique and therefore outcomes are not comparable (Lubatkin 1987; Bower 2001; King et al. 2004). It is also argued that there are as yet unidentified variables that would better explain the variance in acquisitions' performance, whereas others have suggested that the construct measurement for performance is poor (Zollo and Meier 2008). Even though the aggregate annual M\&A market size has reached several trillion US dollars (IMAA 2021), acquiring firms often underperform relative to non-acquiring firms, especially in public takeovers. In a meta-analysis of empirical studies, Renneboog and Vansteenkiste (2019) find that post-takeover deal performance is affected by key determinants including serial acquisitions, CEO overconfidence, acquirer-target relatedness and complementarity, and shareholder intervention in the form of voting or activism.

Emerging markets and, specifically, technology firms in these markets have pursued a significantly large number of M\&A activities since the beginning of this century (Peng et al. 2018). The primary reasons are industries have become more globalized from sourcing, 
production and market perspectives, the domestic economies have become liberalized and access to capital markets in these economies has improved. In addition, intensity of competition has grown. For high-tech firms, the cost, speed and complexity dimensions of technological development pose so much of a challenge that it is not sufficient if they accelerate their R\&D efforts or develop internal innovative capabilities. Thus, even the largest companies are forced to pursue external sources of technology through strategic technology agreements, licensing, or mergers and acquisitions (Vanhaverbeke et al. 2002).

M\&A volume in the Indian market has risen significantly over the past decade, but limited work has taken place on analysis of performance of these M\&A activities. It is also expected that post-acquisition performance in a developing economy such as India may not show findings that are similar to the ones in developed economies because corporate governance mechanisms, size and structure of capital markets, legal frameworks, strategic outlooks, traditions, etc., vary between developed markets and emerging markets. Therefore, there is a need to supplement the current literature on M\&A performance with additional evidence from emerging economies such as India.

This paper analyzes acquisition performance of technology firms in India using a structural equation model (SEM) approach. Using past empirical work and theories on M\&A motives, we build a causal model for post-acquisition performance that consists of measures of long-term financial performance, long-term market performance, short-term market performance and long-term innovation performance as endogenous variables. The model is tested with data on Indian technology firms' M\&A activities over the period of the Indian financial years 1999-2012. Using SEM allows modeling a number of dependent variables and independent variables together and assessment of the strength of various associations among firm-level factors, M\&A transaction factors and firm performance measures.

The remainder of the paper is organized as follows: Section 2 discusses past empirical work, associated theories and the hypotheses; Section 3 elaborates the methodology, variables used and data sources; Section 4 explains the results and implications while Section 5 summarizes the findings and identifies opportunities for future work.

\section{Literature Review and Research Questions}

\subsection{Value Creation through MEA in Emerging Markets}

Since the beginning of the 21st century, emerging economy firms have received increasing attention in the literature, and this has shaped our knowledge of these firms' strategic choices in the context of growth. The three major modes of growth for emerging economy firms - organic, acquisitive and network-based-are driven by the firms' compositional capabilities and frugal innovations for organic growth, affiliation with business groups and appetite for cross-border acquisitions for acquisitive growth, and network capitalism and institutional transitions for network-based growth (Ahsan et al. 2021; Peng et al. 2018). While M\&As have been leveraged by firms in the developed markets for several decades, statistics from IMAA show that emerging market firms have started exploring this growth engine only towards the end of the 20th century (IMAA 2021).

Liberalization of the domestic economy, globalization of industries, increasing intensity of competition and access to capital markets are some of the enablers that have helped emerging market firms explore inorganic growth (Das and Kapil 2015). However, there are differences in value creation patterns in emerging markets acquisitions as compared to those typically observed in developed market acquisitions, due to the nature of the traditional business environments in these markets and their gradual transformation following liberalization (Kale 2004). Lebedev et al. (2015) argue that M\&As within emerging economies are likely to be affected by local institutional and market imperfections to the greatest extent, in comparison to M\&As in developed economies. An institutional void in external capital markets constrains the flow of financial resources, and increases information asymmetry within the economy (Khanna and Palepu 2010). In addition, the corporate disclosure system may be underdeveloped, and institutional intermediaries for diversifying the high fixed cost of information may be lacking. 
Chidambaran et al. (2018) find that both cross-border and domestic acquisitions have increased significantly post-liberalization of the Indian economy, and larger, younger firms, firms with cash on hand, firms with low leverage, and relatively overvalued firms are more likely to pursue acquisitions.

In an extensive analysis of M\&A transactions in 9 emerging economies over 21 years, Kim and Song (2017) demonstrate that capital market development plays a critical role in success of M\&A deals by facilitating the flow of information and capital.

\subsection{Measuring MEA Performance}

Before delving into M\&A performance, it is necessary to understand the nuances of measuring organization performance. Organizations are seen as instruments of multiple purposes, coordinated by visions, strategies and goals. With disparate objectives, organizational performance measurement becomes complex, with a plethora of indicators, e.g., profit, revenue, market share, productivity, debt ratios, stock market prices, R\&D effectiveness, innovation, employee satisfaction, etc. Nonetheless, performance of organization continues to be a focus area in management, organization, and strategy research as it is seen as the benchmark to gauge the effectiveness of managerial decisions and the purpose of the organization.

The different dimensions of performance stem from multiple reasons. First, different stakeholders view an organization differently and stakeholders' expectations of the organization differ. The resources and strategic choices available to each firm are also different and these shape the firms' own performance goals. Finally, performance and activities of the organization have time series implications (Richard et al. 2009).

M\&A performance, a special case of organization performance, has been an equally important research topic among academics and practitioners as there are significant differences in approaches to defining and measuring M\&A performance (Meglio and Risberg 2011; Zollo and Meier 2008). The gains from acquisition synergies could arise due to tax benefits, market power or efficiency improvements. Using value line forecasts, Devos et al. (2009) demonstrate that operating synergies post-acquisition contribute to maximum gain to the combined firm, and such operating synergies are higher in focused mergers due to improved resource allocation. A review of research on M\&A performance reveals that M\&A scholars consider performance of acquirers and targets as one of the most important gauges to assess the outcome of acquisition strategies, and US industries are well studied, compared to businesses elsewhere (Meglio and Risberg 2011). The review also observes that the M\&A performance construct is not a universal construct, but it is sensitive to the research setting. Therefore, M\&A scholars should specify where they measure M\&A performance; also, the ambiguity of the construct makes it essential that M\&A scholars clearly define what it is that they label as M\&A performance. This means scholars need to clearly state if M\&A performance falls within the financial or the non-financial domain or both, over which dimension(s) the performance is measured, and through which indicator(s).

Broadly, the empirical research on M\&A performance has been conducted via two major approaches: event studies and outcome studies. Outcome studies compare the preand post-acquisition performance of a company's stock, and compare the combined firm with matching firms or the base industry (Tichy 2001). However, one of the challenges of outcome studies is the size differential between acquirer and target, as the weighted average financial performance of the target would not contribute significantly to the combined entity's numbers. In addition, identification of similar firms as control groups could become difficult if a large number of companies are engaged in M\&A.

Event studies are used to analyze stock market reactions to the acquirer's and target's stock on the event of an M\&A announcement. This approach assumes that the market is efficient with access to all the information, and therefore changes in the prices of the acquiring and target firms' stocks reflect the value of the economic impact of an acquisition, after adjusting for general market movements. 
Studies across merger waves show that acquisitions result in abnormal loss for acquiring firms in the three-day window and the 21-day window surrounding the acquisition announcement (Alexandridis et al. 2012), suggesting investors' perceptions about the acquirer's inability to create value from acquisitions. This is more pronounced in case of cash-based acquisitions, which suggests that excess liquidity of the acquirer can exacerbate the free-cash flow problem and lead to worse managerial decisions (Harford 1999). Only in situations where there is over-optimism in the market is the short-run abnormal return higher, with an established positive relation between market valuations and short-run acquirer gains (Alexandridis et al. 2012; Bouwman et al. 2009).

While announcement window returns reflect the initial perception of investors at the acquisition announcement, actual value creation may portray a different picture. Alexandridis et al. (2012) find that long-term excess returns for the acquirers are significantly negative for acquisitions in the sixth merger wave, compared to acquisitions in the previous waves. This again provides support for the excess cash flow hypothesis that acquirers, when flush with liquidity and driven by higher market momentum, may resort to managerial herding, leading to value-destroying acquisitions (Bouwman et al. 2009).

The performance measures in empirical studies include both subjective assessment and objective assessment. While subjective assessments focus on synergy realization, effectiveness of post-acquisition integration and reduction of strategic gap, objective assessments focus on financial performance, performance of a company's stock in the stock market and other operational measures. The time horizon varies from short-term (e.g., around the M\&A announcement date) to long-term (up to five years from M\&A announcement). While an announcement period excess return is a typical measure of assessing M\&A performance, it is important to look not only into the short-term change in shareholder value, but also into the longer-term measures and goals to fully estimate success or failure of the acquisition. This call for a broader choice of M\&A performance measures applies to the research on acquisitions in general (Lebedev et al. 2015).

The level of analysis involves improvement of firm performance, its competitive position (e.g., market share) and process efficiency (e.g., quality of post-acquisition plans, proportion of overpay, etc.). Adapting the approach followed by Zollo and Meier (2008), we will focus on three distinct dimensions of acquirer performance: long-term financial/accounting measures, stock market response-related measures and innovation measures. Stock market responses are further classified as short-term and long-term responses.

\subsection{Financial/Accounting Measures}

These measures are firms' financial performance data, which are a universally accepted indicator of firm performance. They assume additional importance after an M\&A transaction due to cost incurred and uncertainty over value created by the acquisition. In a meta-analysis of studies on financial performance of firms, Capon et al. (1990) have investigated how environmental, strategic and organizational factors relate to financial performance. They have found that growth has a consistent positive effect on firm performance, whereas factors like size have inconsistent effects on firm performance. Fowler and Schmidt (1989) have also found that the size of the acquirer does not influence long-term returns like return on equity (ROE). This inconsistency could be explained by the fact that while in certain industries, firm size (in terms of assets or sales volume) helps the firm in reducing its cost and improving its profitability, the same may not be applicable for mature industries or for industries where there are many large competitors. In other research works, it has been demonstrated that size positively influences the long-term return on assets (ROA) (Simerly and Li 2000). Another operating factor that has been studied in past works is the debt-to-equity ratio or financial leverage. It has been found that leverage influences returns such as ROA and long-term ROS negatively (Markides 1995; Simerly and Li 2000), suggesting that the firms with high debts generate lesser returns due to interest payment obligations. 
In the context of technology firms in emerging markets, size plays an important role: a larger firm has a greater access to capital as well as larger capability for R\&D investments, and thus will be in a position to make better use of the acquisition, which in turn should produce relatively higher returns (Kim and Song 2017). In addition, healthy operating factors, measured through debt position and free cash flow, provide support to a firm's growth and integration objectives after acquisition. Therefore,

Hypothesis 1. Larger acquiring firms with strong operating performance produce better long-term financial performance post-acquisition.

Lu and Beamish (2004) have found a curvilinear relationship between R\&D intensity and long-term ROA, while short-term ROA is influenced negatively by R\&D intensity (Vilas-Boas and Suárez-González 2007), suggesting long gestation period to gain from R\&D investment. However, preliminary analysis of Indian acquirers reveals that R\&D intensity in these firms is relatively weak compared to their peers in the developed world and hence we believe R\&D intensity may not have any significant role in long-term financial performance.

Alignment between diversification strategy and entry mode positively influences long-term financial performance (Busija et al. 1997). Similarly, geographic diversification has demonstrated positive or curvilinear relationship with financial performance (Lu and Beamish 2004; Gaur and Kumar 2009). Ramaswamy (1997) has examined the impact of strategic similarities between acquirer and target firms in the US banking industry on changes in post-merger performance measured through ROA, and showed that mergers between banks exhibiting similar strategic characteristics resulted in better performance than those involving strategically dissimilar banks. In a similar study on cross-border acquisitions in Central and Eastern Europe, Uhlenbruck and Castro (2000) have found that industry relatedness and vertical relatedness positively influence ROA of the acquirer. Doukas and Lang (2003) have found that diversifying in core areas results in improvement of operating margins over a period of 2-3 years post-expansion. Other deal characteristics, such as acquirer stake ratio and relative deal size, do influence market performance (Gerbaud and York 2007). It has been found that large deals destroy shareholder value of acquirers on a significant scale (Hu et al. 2020). In addition, Alexandridis et al. (2013) found a robust negative relation between offer premia and target size, and despite this, they such large deals destroy more value for acquirers around deal announcements. This suggests that target size acts as a proxy for complexity associated with post-acquisition integration and generation of synergy. Additionally, the presence of agency effect or managerial hubris will influence long-term financial performance negatively. Therefore, we posit,

Hypothesis 2. High-impact deals, measured through deal size and acquirer stake, produce negative long-term financial performance.

Hypothesis 3. Higher acquirer-target compatibility produces positive long-term financial performance.

\subsection{Market Measures}

Stock market responses to an acquisition announcement provide insights on how markets value the acquisition based on firm-specific factors and transaction parameters. Doukas and Lang (2003) have studied the effect of different firm-specific factors such as firm size, debt position and Tobin's $Q$ on 1-day cumulative abnormal returns (CAR) in firms opting for overseas diversification and, except Tobin's Q, other factors did not influence firms' market performance. High Tobin's $Q$ firms are seen as value-maximizing firms as they engage in investments that enhance operating and internal capital market efficiencies. Capron and Pistre (2002) have studied 21-day CAR for -20 to +1 days during acquisition announcement and have found that only when the acquirer's innovation or managerial resources are transferred to the target will the acquirer receive a positive return. Gerbaud and York (2007) have found that relative deal size and knowledge-seeking acquisition 
positively influence the 1-day CAR of the acquirer. Complementary resources and dynamic complementarities, i.e., the ability to find new ways of combining complementary resources, may produce greater results if the firms in question share some basic features (Lien and Klein 2006). Other researchers have also found that similarity between acquirer and target, enabling positive transfer of knowledge, results in positive acquisition performance measured through announcement time CAR (Finkelstein and Haleblian 2002; Hayward 2002). However, Ben-David et al. (2020) showed that, contrary to the widely-held view of announcement returns being reflective of long-term acquisition outcomes, they are uncorrelated, casting doubt on the usefulness of announcement returns.

In an analysis of Indian firms, Kumar and Paneerselvam (2009) have shown that abnormal returns of the acquirers involved in acquisitions showed positive abnormal gains only in a shorter time window. Nagano and Yuan (2007) have studied acquisitions in India and China and have found that stake ratio has a positive impact on 3-day CAR, and cross-border acquisitions produce better CAR than domestic acquisitions. Seth et al. (2002) have found that relative deal size had a positive influence on CAR, and synergy-seeking acquirers with high intangible assets demonstrated positive CAR. However, a broad analysis of Indian acquisitions reveals that the market tends to react negatively towards large deals, fearing over-valuation of targets. Similarly, Reddy et al. (2019) observed that on average, M\&A announcements do not create value for the firms in Chinese and Indian economies. On the other hand, contrary to findings from many empirical studies on postacquisition market returns, Bhabra and Huang (2013) found that in Chinese M\&A markets, acquirers experience significant positive abnormal stock returns around the announcement date and over three years post-announcement, providing support for the synergy motive. This indicates Chinese M\&As are viewed by investors positively. They observe that one of the key factors that contribute to a positive announcement period return is industry relatedness of the acquirer and the target.

Thus, we argue, if an acquisition suggests possibilities of dynamic complementarities through acquirer-target relatedness, short-term market response to the acquisition is expected to be positive, as they would outperform firms with unrelated combinations of activities and single-business firms. In addition, the presence of intangible assets provides an indicator of an acquirer's growth opportunities, and a higher Tobin's Q indicates the quality of the acquirer's current and future investment. However, market response is muted when the size of the deal goes up. Therefore, we propose:

Hypothesis 4. Higher acquirer-target compatibility results in positive short-term gain for the acquirer.

Hypothesis 5. High-impact deals, measured through relative deal size and acquirer stake, produce negative short-term gains for the acquirer.

Hypothesis 6. Acquirers with higher intangible assets produce positive short-term gains for the acquirer.

In comparison to a large number of event studies on short-term announcement period returns, empirical studies on long-term market returns post-acquisition are limited. In a study of long-term market performance post-acquisition, Alhenawi and Krishnaswami (2015) documented that excess value was positive for related mergers while it was negative for unrelated mergers in each of the five years following the merger. Similarly, André et al. (2004) have found that relatedness between acquirer and target resulted in a positive alpha from a Fama-French 3-factor (FFTF) model over a 3-year measurement period, and for the same period book-to-market ratio had a negative influence on alpha. Francoeur (2006) has evaluated the long-term financial performance of acquiring firms in cross-border M\&As of Canadian firms using a control-firm approach in event time and FFTF in calendar time. He has found that Canadian firms carrying out cross-border M\&As managed to generate higher than market returns by leveraging R\&D and intangibles. This is in line 
with the findings of Doukas and Lang (2003) that Tobin's Q positively influences acquirers' long-term buy and hold abnormal returns (BHAR). Lin et al. (2006) posited that a firm's commercialization orientation, rather than R\&D effort, contribution to firm performance.

We have proposed that an acquirer's healthy operating performance results in positive financial performance post-acquisition, and that extends to long-term market performance. In addition, we argue for the presence of an agency effect in acquisition decisions and posit that large deals result in erosion of long-term market value of the acquirer. Therefore,

Hypothesis 7. Acquiring firms with strong operational performance produce positive long-term market performance.

Hypothesis 8. Large deals, measured through relative deal size, produce negative long-term market performance.

Hypothesis 9. Acquiring firms with higher intangible assets produce positive long-term market performance.

\subsection{Innovation Measures}

Limited empirical work has been carried out on the effect of acquisitions on long-term innovation performance of the acquirer post-acquisition. Cloodt et al. (2006) have found that non-technological M\&As show a negative impact on the acquirer's post-acquisition innovation performance. However, one of the primary motives of a technology acquirer would be enhancement of innovative capability of the firm. We argue that post-acquisition, the acquirer will be in a better position to combine and leverage its own innovative capabilities with those of the target. Therefore,

Hypothesis 10. The acquirer's technology investments and other intangible assets result in positive long-term innovation performance.

Hypothesis 11. Acquirer-target relatedness results in positive long-term innovation performance.

\section{Methodology}

\subsection{Applying SEM for MEA Performance Modeling}

The structural equation modeling approach has been chosen to estimate influence of firm-level factors and transaction parameters on post-acquisition performance, using $\mathrm{AMOS}^{\mathrm{TM}} 18$, software that uses a variance-covariance matrix for estimation. The causal modeling procedure of SEM is appropriate to test the hypothesized model as it considers multiple path coefficients simultaneously. This allows analysis of direct, indirect and spurious relationships among variables simultaneously and estimation of individual weightings of each observed variable in the context of the theoretical model. The process also takes care of measurement errors, inter-construct residual error, reciprocal causation, simultaneity and interdependence (Capron et al. 2001).

A SEM typically consists of an inner structural model and outer measurement model (Capron 1999). The form of the inner structural model is:

$$
\eta=\beta \cdot \eta+T \cdot \xi+\zeta
$$

where $\eta$ is a vector of latent endogenous variables of size $(p \times 1), \xi$ is a vector of latent exogenous variables of size $(q \times 1), \beta$ is a matrix of endogenous variable coefficients of size $(p \times p)$, $T$ is a matrix of exogenous variable coefficients of size $(p \times q)$ and $\zeta$ is a vector of residuals of size $(p \times 1)$. The form of the outer measurement model for m number of endogenous variables represented by $y$ is given by:

$$
\mathrm{y}=\Lambda_{\mathrm{y}} \cdot \eta+\varepsilon
$$


where $y$ is a vector of endogenous indicators of size $(m \times 1), \Lambda_{y}$ is a matrix of regression coefficients of $\eta$ on $y$ of size $(m \times p)$, and $\varepsilon$ is a vector of measurement error for indicators of endogenous variables of size $(\mathrm{m} \times 1)$.

The form of the outer measurement model for $n$ number of exogenous variables represented by $\mathrm{x}$ is given by:

$$
\mathrm{x}=\Lambda_{\mathrm{x}} \cdot \xi+\delta
$$

where $x$ is a vector of exogenous indicators of size $(n \times 1), \Lambda_{x}$ is a matrix of regression coefficients of $\xi$ on $x$ of size $(n \times q)$, and $\delta$ is a vector of measurement error for indicators of exogenous variables of size $(n \times 1)$.

In the model construct, we do away with exogenous latent variables and we model firm-specific factors and transaction characteristics (i.e., exogenous measurement variables) directly with four endogenous latent variables, each representing a type of performance measure, and these four latent variables in turn map on to one or more endogenous measurement variables. We estimate the causal model using the "full information maximum likelihood" procedure, an efficient estimator when there is missing data (Capron 1999).

The goodness-of-fit of the model is assessed using absolute, relative and comparative fit indices. The absolute fit chi-square is derived from the fit of the obtained and implied covariance matrix and the maximum likelihood (ML) minimization function. However, as it is affected by sample size, model size, distribution of variables and omitted variables, it is not an effective measure of fit. The relative fit includes the relative chi-square, i.e., the chi-square scaled down by degrees of freedom. A value of 3.0 or less for the relative chi-square is treated as a good fit. The comparative fit index (CFI) compares the chi-square of the tested model with independence or a null model and a value of 0.9 is treated as a good fit. Root mean square error of approximation (RMSEA) is another index based on non-centrality where a model chi-square is tested against a non-central chi-square and a value less than 0.7 indicates good fit.

\subsection{Variables}

The variables for the empirical test are listed in Table 1 along with associated definitions. The four endogenous latent variables, i.e., long-term financial performance and long-term innovation performance, long-term market performance and short-term market performance, map on to one or more indicators of performance. Long-term financial performance is represented by three variables: proportional changes in ROS, ROA and ROCE over two years. Long-term innovation performance is measured through changes in patent stock over two years weighted by size of the firm. Long-term market performance is evaluated through the FFTF alpha over a period of 24 months while short-term market performance is calculated through the 21-day cumulative average abnormal return around announcement time.

Researchers have used a time lag from one year to six years to evaluate the effect of M\&A (Hagedoorn and Duysters 2002). While too short a lag may not demonstrate any impact of acquisition, a longer lag confounds the effects of several events on performance measures, especially in a dynamic industry like the technology sector. Therefore, we studied performance measures after two years from the date of acquisition announcement, except for short-term market performance that was studied from -20 days to +1 day around the date of announcement (Capron and Pistre 2002). Event studies have been carried out with different ranges, as information on M\&A reaches the market before actual announcements, and it is reasonable to believe that market reaction associated with announcements should be studied much in advance and should not continue for long after announcements. The following sections explain calculation of the FFTF alpha and cumulative abnormal returns. 
Table 1. Variable definitions and data sources.

\begin{tabular}{|c|c|c|c|}
\hline Variable Category & Variable Name * & Explanation/Calculation/Values & Data Source \\
\hline Latent Endogenous & Long-term market perf. & $\begin{array}{l}\text { Long-term performance on stock } \\
\text { market }\end{array}$ & NA \\
\hline Endogenous Indicator & FFTF alpha (FY-FY+2) & $\begin{array}{l}\text { Alpha from FF-TFPM over } 2 \text { years } \\
\text { (see calculation for FFTF-Alpha) }\end{array}$ & $\begin{array}{l}\text { CMIE Prowess, RBI } \\
\text { Publications }\end{array}$ \\
\hline Latent Endogenous & Short-term market perf. & $\begin{array}{l}\text { Short-term performance in stock } \\
\text { market }\end{array}$ & NA \\
\hline Endogenous Indicator & $\begin{array}{l}\text { Cumulative abnormal returns } \\
\text { (short-term) }\end{array}$ & $\begin{array}{l}\text { Short-term cumulative abnormal } \\
\text { return over period }-20 \text { days to }+1 \\
\text { day (see calculation for CAR) }\end{array}$ & CMIE Prowess \\
\hline Latent Endogenous & Long-term financial perf. & $\begin{array}{l}\text { Long-term performance of financial } \\
\text { ratios }\end{array}$ & NA \\
\hline Endogenous Indicator & Change in ROA (FY-FY+2) & $\begin{array}{l}\text { Change in return on assets over } 2 \\
\text { years }\end{array}$ & CMIE Prowess \\
\hline Endogenous Indicator & Change in ROS (FY-FY+2) & Change in return on sales over 2 years & CMIE Prowess \\
\hline Endogenous Indicator & Change in ROCE (FY-FY+2) & $\begin{array}{l}\text { Change in return on capital employed } \\
\text { over } 2 \text { years }\end{array}$ & CMIE Prowess \\
\hline Latent Endogenous & Long-term innovation perf. & $\begin{array}{l}\text { Long-term performance on } \\
\text { innovation }\end{array}$ & NA \\
\hline Endogenous Indicator & R\&D effectiveness $(F Y+2)$ & $\begin{array}{l}\text { R\&D effectiveness = patent stock after } \\
2 \text { years of acquisition weighted by } \\
\text { size (sales volume) }\end{array}$ & $\begin{array}{l}\text { Worldwide patent database of } \\
\text { European Patent Office, CMIE } \\
\text { Prowess }\end{array}$ \\
\hline Exogenous Indicator & $\mathrm{Q}$ ratio $(\mathrm{FY})$ & $\begin{array}{l}\text { Proxy for Tobin's } \mathrm{Q}=\text { market value of } \\
\text { equity plus the book value of debt } \\
\text { divided by the book value of assets }\end{array}$ & CMIE Prowess \\
\hline Exogenous Indicator & R\&D intensity (FY) & $\begin{array}{l}\text { R\&D intensity }=R \& D \text { expense } / \text { total } \\
\text { sales }\end{array}$ & CMIE Prowess \\
\hline Exogenous Indicator & Log of total assets (FY) & $\begin{array}{l}\text { Acquirer size }=\log \text { (total assets in } \\
\text { million rupees from balance sheet) }\end{array}$ & CMIE Prowess \\
\hline Exogenous Indicator & Cash flow/share (FY) & $\begin{array}{l}\text { Cash flow }=\text { net cash inflow for cash } \\
\text { flow statement } / \text { number of shares } \\
\text { outstanding }\end{array}$ & CMIE Prowess \\
\hline Exogenous Indicator & Total debt/total equity (FY) & $\begin{array}{l}\text { Leverage }=\text { total debt divided by } \\
\text { shareholder equity }\end{array}$ & CMIE Prowess \\
\hline Exogenous Indicator & Book to market ratio (FY) & $\begin{array}{l}\text { Book to market ratio = book value } \\
\text { divided by market cap }\end{array}$ & CMIE Prowess \\
\hline Exogenous Indicator & Acquirer-target compatibility & $\begin{array}{l}\text { Mapped on a scale of } 0-1 \text { based on } \\
\text { relatedness between acquirer and } \\
\text { target by their core area of operation }\end{array}$ & CMIE Prowess and EMIS \\
\hline Exogenous Indicator & Relative deal size & $\begin{array}{l}\text { Purchase price divided by market cap } \\
\text { of acquirer at the time of purchase }\end{array}$ & CMIE Prowess and EMIS \\
\hline Exogenous Indicator & Stake scale & $\begin{array}{l}\text { Mapped on a scale of } 0-1 \text { based on } \\
\text { acquired stake }\end{array}$ & CMIE Prowess and EMIS \\
\hline
\end{tabular}

* FY: Year of acquisition, FY-FY+2: Change over two years, FY+2: 2 years post-acquisition, FY-FY+2: Monthly calculation from acquisition announcement for 2 years.

\subsection{Calculation of FFTF Alpha}

The Fama-French three-factor model is expressed as follows:

$$
\mathrm{R}_{\mathrm{at}}-\mathrm{R}_{\mathrm{ft}}=\alpha+\beta \cdot\left(\mathrm{R}_{\mathrm{mt}}-\mathrm{R}_{\mathrm{ft}}\right)+\mathrm{s} \cdot \mathrm{SMB}_{\mathrm{t}}+\mathrm{h} \cdot \mathrm{HML} \mathrm{t}+\varepsilon_{\mathrm{i}}
$$


where $R_{a t}$ is the average monthly return of the acquiring firm's stock, $R_{\mathrm{ft}}$ is the monthly risk-free return on the stock market and $\mathrm{R}_{\mathrm{mt}}$ is the monthly return of the value-weighted market index. $\mathrm{SMB}_{\mathrm{t}}$ is the difference between the value-weighted return on small firms on the stock market and value-weighted returns on large firms on the stock market. $\mathrm{HML}_{\mathrm{t}}$ is the difference of the value-weighted return on high book-to-market firms on the stock market and the value-weighted return on low book-to-market firms on the stock market. Coefficients $\beta, \mathrm{s}$ and $\mathrm{h}$ are regression parameters while $\varepsilon$ is the error term.

From the month of acquisition announcement, for each month over a period of 24 months, the following were tabulated:

- $\mathrm{R}_{\mathrm{at}}$ : Monthly stock return

- $\mathrm{R}_{\mathrm{ft}}$ : Risk-free return for the month from Reserve Bank of India (RBI) published data

- $\mathrm{R}_{\mathrm{mt}}$ : Average market return for the month

- $\mathrm{SMB}_{\mathrm{t}}$ : Difference in return of small firms' stock and big firms' stock on BSE

- HML $_{\mathrm{t}}$ : Difference in return of high-book value firms' stock and low book value firms' stock on BSE.

These series of data were put to a regression test and $\alpha$ was estimated for the firms for this period. This was done for each transaction in the dataset for all the companies listed on the stock exchange.

\subsection{Calculation of Cumulative Abnormal Returns (CAR)}

CAR is the abnormal return for acquirer stock around the announcement date of acquisition. The market model of stock return can be expressed as:

$$
R_{i t}=\alpha_{i}+\beta_{i} \cdot R_{m t}
$$

where $R_{i t}$ is the daily return for acquirer firm i on day $t ; \alpha_{i}$ is the alpha, a measure of excess return of the acquirer firm i's stock; $\beta_{i}$ is the beta of the acquirer firm i, i.e., a coefficient that can measure the volatility of firm i's stock compared to the systematic risk of the entire market; $R_{\mathrm{mt}}$ is the return on the market portfolio on day $t$.

The OLS regression procedure was used to estimate the parameters for $\alpha$ and $\beta, \hat{\alpha}$ and $\hat{\beta}$ respectively. The daily abnormal return was calculated for 3 weeks of data, from 20 days prior to announcement to one day after the event date through the following equation:

$$
\mathrm{AR}_{\mathrm{it}}=\mathrm{R}_{\mathrm{it}}-\hat{\alpha}-\hat{\beta} \mathrm{R}_{\mathrm{mt}} \text { for } \mathrm{t}=-20 \text { to }+1
$$

Finally: the cumulative abnormal return for the acquiring firm i was calculated as:

$$
\mathrm{CAR}_{\mathrm{t}}=\sum_{\mathrm{t}=-20}^{\mathrm{t}=1} \mathrm{AR}_{\mathrm{it}}
$$

The exogenous variables in the model are of two types: firm operational indicators and M\&A transaction characteristics. To test Hypotheses H1 and H7, we used firm level operational variables, log of total a(representing acquirer size), cash flow/share, total debt/total equity and book-to-market ratio as reported for the acquirer in the year of acquisition. To test Hypotheses $\mathrm{H} 2-\mathrm{H} 6$ we used M\&A transaction-specific variables, acquirer-target compatibility, relative deal size and stake scale. To test Hypotheses $\mathrm{H} 6$ and H9-H11 we used acquirers' intangible assets and R\&D-related variables: Tobin's $Q$ and R\&D intensity.

\subsection{Data Sample}

Firms were selected based on industry classification codes. Indian firms categorized under codes of 334 (i.e., computer and electronic manufacturing), 51 (i.e., information including IT, telecoms and media) and 54 (i.e., professional, scientific and technical services) that had acquired one or more firms over a period of 13 financial years were identified from the EuroMoney ISI Emerging Markets database (EMIS). For each of the 677 M\&A transactions, involving 372 acquiring firms, during this period firm-level data as well as 
stock market performance data were extracted from the PROWESS database, which is published by the Centre for Monitoring the Indian Economy (CMIE). Thus, the resulting dataset contained 677 data rows and the columns pertaining to all the base data items, and derived variables from the base data. Derived variables that included 21-day CAR and 24 months' FFTF alpha values were calculated from this data. The market benchmark index used here was the Bombay Stock Exchange's SENSEX. For certain transactions we did not have a complete set of information; however, these records were retained for analysis.

\section{Findings and Discussion}

The descriptive statistics pertaining to exogenous and endogenous indicators corresponding to 677 deals involving 3 acquirers over the period of 13 years are presented in Table 2.

Table 2. Descriptive statistics.

\begin{tabular}{|c|c|c|c|c|c|c|}
\hline Variable Name & Unit & $\mathbf{N}$ & Minimum & Maximum & Mean & $\begin{array}{c}\text { Std. } \\
\text { Deviation }\end{array}$ \\
\hline $\begin{array}{l}\text { FFTF alpha } \\
\text { (FY-FY+2) }\end{array}$ & Number & 658 & -3.607 & 7.762 & -0.478 & 1.084 \\
\hline $\begin{array}{l}\text { Cumulative } \\
\text { Abnormal Returns } \\
\text { (Short-Term) }\end{array}$ & $\%$ & 677 & -92.956 & 116.243 & 0.837 & 20.298 \\
\hline $\begin{array}{c}\text { Change in ROA } \\
(\text { FY-FY }+2)\end{array}$ & $\%$ & 530 & -1.099 & 2.241 & -0.004 & 0.200 \\
\hline $\begin{array}{c}\text { Change in ROS } \\
\text { (FY-FY+2) }\end{array}$ & $\%$ & 519 & -116.069 & 728.492 & 0.774 & 32.764 \\
\hline $\begin{array}{c}\text { Change in ROCE } \\
(\mathrm{FY}-\mathrm{FY}+2)\end{array}$ & $\%$ & 512 & -1.347 & 2.059 & -0.021 & 0.255 \\
\hline $\begin{array}{l}\text { R\&D Effectiveness } \\
\qquad(\mathrm{FY}+2)\end{array}$ & Ratio & 580 & 0.000 & 2.344 & 0.105 & 0.314 \\
\hline Q Ratio (FY) & Ratio & 391 & 1.031 & 98.162 & 3.830 & 7.449 \\
\hline $\begin{array}{l}\text { R\&D Intensity } \\
\text { (FY) }\end{array}$ & Ratio & 137 & 0.000 & 0.185 & 0.029 & 0.038 \\
\hline $\begin{array}{l}\text { Log of Total } \\
\text { Assets (FY) }\end{array}$ & Number & 590 & 13.122 & 28.076 & 22.562 & 2.022 \\
\hline $\begin{array}{c}\text { Cash Flow/Share } \\
\text { (FY) }\end{array}$ & $\begin{array}{l}\text { Indian } \\
\text { Rupee }\end{array}$ & 536 & -265.153 & 1508.000 & 9.661 & 95.457 \\
\hline $\begin{array}{c}\text { Total Debt/Total } \\
\text { Equity (FY) }\end{array}$ & Ratio & 590 & 0.000 & 34.690 & 0.753 & 2.086 \\
\hline $\begin{array}{c}\text { Book to Market } \\
\text { Ratio (FY) }\end{array}$ & Ratio & 391 & -0.202 & 17.648 & 0.766 & 1.400 \\
\hline $\begin{array}{l}\text { Acquirer Target } \\
\text { Compatibility }\end{array}$ & $\begin{array}{l}\text { Range } \\
{[0-1]}\end{array}$ & 677 & 0.200 & 1.000 & 0.396 & 0.301 \\
\hline Relative Deal Size & Number & 159 & 0.000 & 9.009 & 0.258 & 1.116 \\
\hline Stake Scale & $\begin{array}{l}\text { Range } \\
{[0-1]}\end{array}$ & 677 & 0.200 & 1.000 & 0.662 & 0.272 \\
\hline
\end{tabular}

SEM analysis was conducted on data from 677 M\&A activities with the AMOS ${ }^{\mathrm{TM}}$ 18 statistical package. Circles represent latent variables and rectangles represent measure variables. The standardized coefficients and corresponding significance are shown in Table 3. 


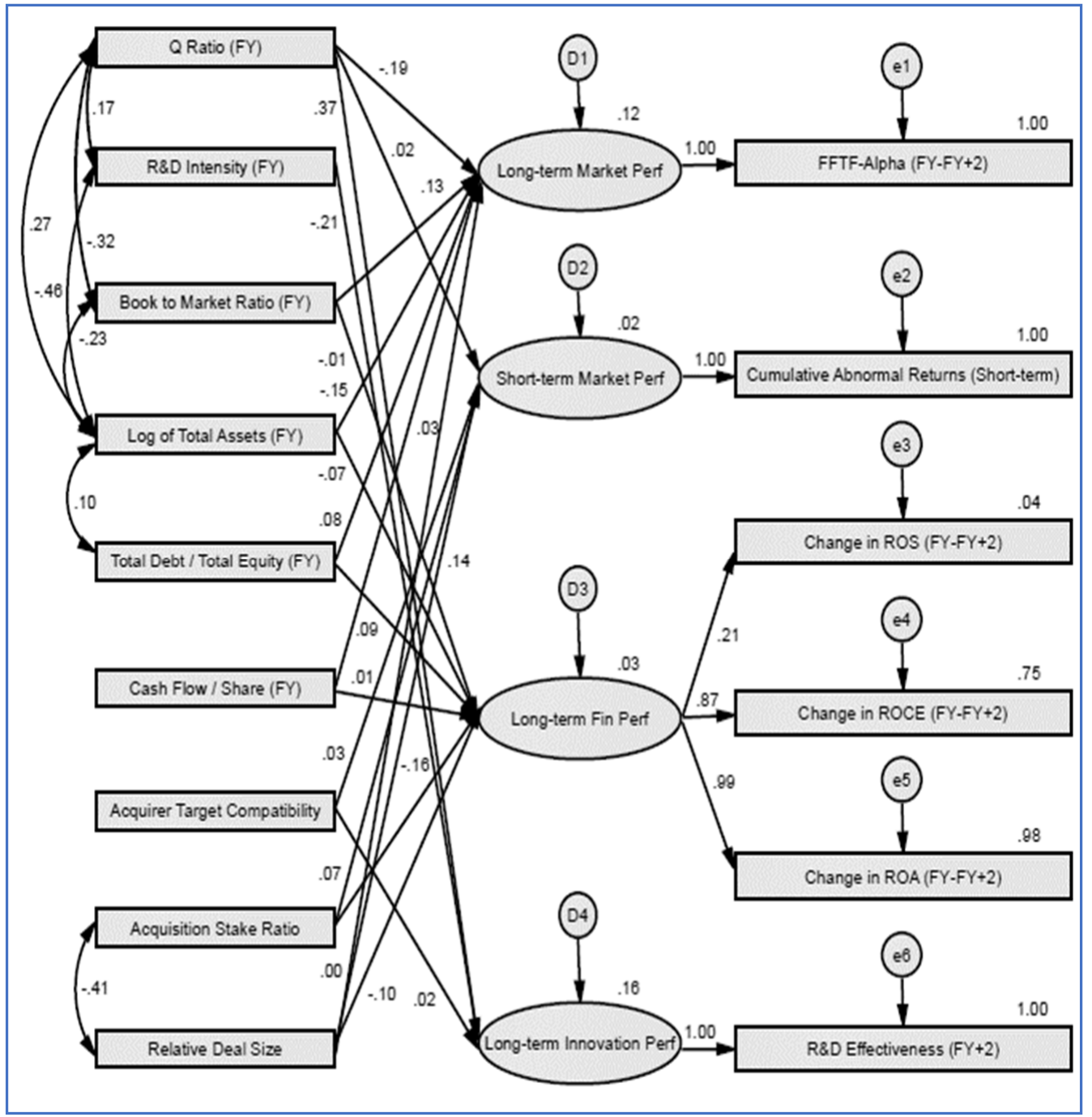

Figure 1. Standardized path diagram of M\&A performance model.

Table 3. Unstandardized and standardized coefficients, and significance levels for the model in Figure 1 (standard errors in parenthesis; $\mathrm{N}=677$ ).

\begin{tabular}{cccccc}
\hline \multicolumn{2}{c}{ Parameter Estimate } & Unstandardized & Standardized & $p$-Value \\
\hline $\begin{array}{c}\text { Long-Term Fin. } \\
\text { Perf. }\end{array}$ & $\leftarrow$ & $\begin{array}{c}\text { Book to Market } \\
\text { Ratio (FY) }\end{array}$ & $-0.010(0.036)$ & -0.014 & 0.783 \\
\hline $\begin{array}{c}\text { Long-Term Fin. } \\
\text { Perf. }\end{array}$ & $\leftarrow$ & $\begin{array}{c}\text { Log of Total Assets } \\
(\text { FY) }\end{array}$ & $-0.036(0.023)$ & -0.072 & 0.112 \\
\hline $\begin{array}{c}\text { Long-Term Fin. } \\
\text { Perf. }\end{array}$ & $\leftarrow$ & $\begin{array}{c}\text { Total Debt/Total } \\
\text { Equity (FY) }\end{array}$ & $0.043(0.021)$ & 0.087 & $0.044^{*}$ \\
\hline $\begin{array}{c}\text { Long-Term Fin. } \\
\text { Perf. }\end{array}$ & $\leftarrow$ & Stake Scale & $-0.608(0.238)$ & -0.162 & $0.011^{* *}$ \\
\hline
\end{tabular}


Table 3. Cont.

\begin{tabular}{|c|c|c|c|c|c|}
\hline \multicolumn{3}{|c|}{ Parameter Estimate } & \multirow{2}{*}{$\begin{array}{c}\text { Unstandardized } \\
-0.091(0.095)\end{array}$} & \multirow{2}{*}{$\begin{array}{c}\text { Standardized } \\
-0.105\end{array}$} & \multirow{2}{*}{$\begin{array}{c}p \text {-Value } \\
0.334\end{array}$} \\
\hline $\begin{array}{l}\text { Long-Term Fin. } \\
\text { Perf. }\end{array}$ & $\leftarrow$ & Relative Deal Size & & & \\
\hline $\begin{array}{l}\text { Long-Term Fin. } \\
\text { Perf. }\end{array}$ & $\leftarrow$ & $\begin{array}{l}\text { Cash Flow/Share } \\
\text { (FY) }\end{array}$ & $0.000(0.000)$ & 0.014 & 0.750 \\
\hline $\begin{array}{c}\text { Long-Term } \\
\text { Innovation Perf. }\end{array}$ & $\leftarrow$ & $\begin{array}{l}\text { Acquirer- Target } \\
\text { Compatibility }\end{array}$ & $0.073(0.147)$ & 0.020 & 0.621 \\
\hline $\begin{array}{c}\text { Long-Term } \\
\text { Innovation Perf. }\end{array}$ & $\leftarrow$ & R\&D Intensity (FY) & $-6.295(1.733)$ & -0.210 & $* * *$ \\
\hline $\begin{array}{c}\text { Long-Term } \\
\text { Innovation Perf. }\end{array}$ & $\leftarrow$ & Q Ratio (FY) & $0.155(0.024)$ & 0.374 & $* * *$ \\
\hline $\begin{array}{l}\text { Short-Term } \\
\text { Market Perf. }\end{array}$ & $\leftarrow$ & Stake Scale & $0.252(0.202)$ & 0.068 & 0.213 \\
\hline $\begin{array}{l}\text { Short-Term } \\
\text { Market Perf. }\end{array}$ & $\leftarrow$ & Relative Deal Size & $0.123(0.073)$ & 0.142 & 0.092 \\
\hline $\begin{array}{l}\text { Short-Term } \\
\text { Market Perf }\end{array}$ & $\leftarrow$ & $\begin{array}{c}\text { Acquirer Target } \\
\text { Compatibility }\end{array}$ & $0.099(0.129)$ & 0.030 & 0.441 \\
\hline $\begin{array}{l}\text { Short-Term } \\
\text { Market Perf. }\end{array}$ & $\leftarrow$ & Q Ratio (FY) & $0.009(0.017)$ & 0.023 & 0.606 \\
\hline $\begin{array}{l}\text { Long-Term } \\
\text { Market Perf. }\end{array}$ & $\leftarrow$ & $\begin{array}{c}\text { Book to Market } \\
\text { Ratio (FY) }\end{array}$ & $0.097(0.040)$ & 0.129 & $0.015^{* *}$ \\
\hline $\begin{array}{l}\text { Long-Term } \\
\text { Market Perf. }\end{array}$ & $\leftarrow$ & Q Ratio (FY) & $-0.076(0.023)$ & -0.188 & $* * *$ \\
\hline $\begin{array}{l}\text { Long-Term } \\
\text { Market Perf. }\end{array}$ & $\leftarrow$ & $\begin{array}{l}\text { Total Debt/Total } \\
\text { Equity (FY) }\end{array}$ & $0.040(0.021)$ & 0.078 & 0.055 \\
\hline $\begin{array}{l}\text { Long-Term } \\
\text { Market Perf }\end{array}$ & $\leftarrow$ & $\begin{array}{c}\text { Cash Flow/Share } \\
\text { (FY) }\end{array}$ & $0.000(0.000)$ & 0.027 & 0.501 \\
\hline $\begin{array}{l}\text { Long-Term } \\
\text { Market Perf }\end{array}$ & $\leftarrow$ & $\begin{array}{l}\text { Log of Total Assets } \\
\text { (FY) }\end{array}$ & $-0.078(0.023)$ & -0.148 & $* * *$ \\
\hline $\begin{array}{l}\text { Long-Term } \\
\text { Market Perf. }\end{array}$ & $\leftarrow$ & Relative Deal Size & $0.001(0.057)$ & 0.002 & 0.980 \\
\hline $\begin{array}{l}\text { FFTF Alpha } \\
(\text { FY-FY+2) }\end{array}$ & $\leftarrow$ & $\begin{array}{c}\text { Long-Term Market } \\
\text { Perf }\end{array}$ & $1.018(0.030)$ & 1.000 & $* * *$ \\
\hline $\begin{array}{l}\text { Cumulative } \\
\text { Abnormal } \\
\text { Returns } \\
\text { (Short-Term) }\end{array}$ & $\leftarrow$ & $\begin{array}{c}\text { Short-term Market } \\
\text { Perf. }\end{array}$ & $20.093(0.574)$ & 1.000 & $* * *$ \\
\hline $\begin{array}{c}\text { Change in ROA } \\
(\text { FY-FY+2) }\end{array}$ & $\leftarrow$ & Long-Term Fin. Perf. & $0.196(0.012)$ & 0.989 & $* * *$ \\
\hline $\begin{array}{c}\text { Change in ROS } \\
(\mathrm{FY}-\mathrm{FY}+2)\end{array}$ & $\leftarrow$ & Long-Term Fin. Perf. & 1.000 (NA) & 0.207 & NA \\
\hline $\begin{array}{c}\text { Change in ROCE } \\
(\text { FY-FY+2) }\end{array}$ & $\leftarrow$ & Long-Term Fin. Perf. & $0.217(0.014)$ & 0.868 & $* * *$ \\
\hline $\begin{array}{c}\text { R\&D } \\
\text { Effectiveness } \\
(F Y+2)\end{array}$ & $\leftarrow$ & $\begin{array}{c}\text { Long-Term } \\
\text { Innovation Perf. }\end{array}$ & $0.502(0.016)$ & 1.000 & $* * *$ \\
\hline
\end{tabular}

Note: $\mathrm{N}=677, \chi^{2}(77)=204.023, p<0.001, \mathrm{CMIN} / \mathrm{DF}=2.650, \mathrm{CFI}=0.875, \mathrm{RMSEA}=0.049 ; * * *$ Significant at $99 \%$ level, ** Significant at $95 \%$ level, * Significant at $90 \%$ level. 
The path diagram is shown in Figure 1. We evaluated the assumptions of multivariate normality and linearity. Maximum likelihood parameter estimation was chosen because the data were distributed close to normal. The hypothesized model appeared to be a good fit to the data. The relative chi-square (CMIN/DF) was 2.650, CFI was 0.875; TLI was 0.805; and the RMSEA was 0.049 . Post hoc modifications were not conducted because of the good fit of the data to the model.

\subsection{Explaining Long-Term Financial Performance}

We found no support for hypothesis H1, partial support for hypothesis $\mathrm{H} 2$ and no support for hypothesis H3. Long-term financial performance of acquirers was positively influenced by only by total debt/total equity and stake scale, while other variables did not appear to have significant impact.

Among all operational factors, highly leveraged acquirers produced better long-term financial performance measured through proportional changes in ROS, ROA and ROCE. While this deviated from some of the earlier findings, it reinforces the fact that acquirers with easy access to cash tended to produce inferior results. This also deviated from some of the earlier findings that a high debt-equity ratio negatively influences profitability of the acquirer (Markides 1995; Simerly and Li 2000). However, the findings here can be explained in the context of Jensen's FCF hypothesis. A large proportion of acquisitions in emerging markets are cash deals and in cash-dominated M\&A transactions, acquirers with easy access to cash tend to produce inferior results. Our results align with some of the earlier results that indicate that in cases of cash-based acquisitions, excess liquidity of the acquirer can exacerbate the free-cash flow problem and lead to worse managerial decisions (Harford 1999).

While relative deal size and acquirer-target compatibility do not seem to have significant influence on long-term financial performance, what makes a significant difference is the acquirer's stake in the target. A higher stake potentially results in better control and integration post-acquisition and that probably helps the acquirer to make best use of the target's resources, resulting into superior financial performance in the long run.

\subsection{Explaining Market Performance}

We did not find support for Hypotheses H4-H6. In our model, short-term market performance did not demonstrate any association with the exogenous variables. This is in contrast with several earlier studies that have found a strong relationship between deal size and acquirer-target relatedness and market reaction to the acquisition announcement (e.g., Seth et al. 2002; Lien and Klein 2006). Inconsistent market reaction at announcement time can be explained by the possible presence of other unknown influencers. Valuation of the target plays an important role in market reaction during the announcement time.

Contrary to the findings of Doukas and Lang (2003), we did not find any influence of intangibility measured by Tobin's $Q$ on short-term market performance. As valuemaximizing firms (high $Q$ firms) are not perceived to engage in expansions perceived to create shareholder value, one would expect either presence of hubris and agency effect in these acquisitions or presence of another influence that impacts short-term market performance.

However, looking at long-term market performance, we found partial support for hypothesis $\mathrm{H} 7$ and no support for Hypotheses H8 and H9: acquirers with high intangible assets deliver significantly lesser long-term market returns, again contradicting the concept that firms with a high $Q$ ratio tend to maximize the benefits of their intangible assets. We also note that larger acquirers produced lesser long-term market gains that suggest that relatively smaller acquirers are able to demonstrate value of acquisitions better to their shareholders. Firms with a higher book value and higher leverage demonstrated better long-term market performance in this study, contradicting André et al. (2004). 


\subsection{Explaining Long-Term Innovation Performance}

In line with the findings of Cloodt et al. (2006), we found strong support for hypothesis H10 but not for hypothesis H11. Both the R\&D intensity of the acquirer and the acquirer's $Q$ ratio had a strong positive relationship with long-term innovation performance. This suggests effective technological integration post-acquisition, i.e., acquirers were able to leverage their R\&D investment and other intangible assets effectively in conjunction with their targets' products and services. However, if acquirer-target relatedness shows no influence on acquirer's post-acquisition innovation performance, it weakens the argument that relatedness improves complementary asset leverage and dynamic complementarities (Lien and Klein 2006), and this requires further investigation.

\section{Conclusions and Directions for Future Research}

This study constructed an M\&A performance model for the acquirer based on the concepts of firm performance and implications of M\&A transactions for the acquirer. Though firm performance is a widely researched area, past works have been moderated by opportunities and constraints: objectives of individual researchers, perceptions of what is firm performance and availability of data (or lack of it) have played important roles in empirical research in this area. As M\&A performance cannot be measured through one single construct that encompasses all aspects of a firm's performance following an acquisition, we have introduced multiple measures and identified independent variables that could influence these outcomes. The independent variables either were firm-level operating factors at the time of acquisition or related to characteristics of acquisition transactions. A structural equation model was adopted primarily because it allows modeling of several dependent and independent variables together in a single structure.

The hypotheses were based on analysis of past research and observations on focal industry segments. We found that long-term financial performance was positively influenced by leverage and negatively influenced by the acquirer's stake ratio, suggesting presence of an agency effect. Long-term market performance was positively influenced by book value of the firm and negatively influenced by the presence of intangible assets and acquirer size, suggesting that acquirers, specifically large acquirers, are not able to demonstrate value creation over a longer period through their intangible assets. We did not find any influencing factor for short-term market performance, indicating the possible presence of other factors not considered in this study. On the other hand, long-term innovation performance showed a strong positive relationship with acquirers' R\&D intensity and intangible assets, suggesting that acquirers are able to leverage their intangible assets toward innovative results post-acquisition.

The model developed in this paper does have a few limitations. First, external validation with a new M\&A and firm performance dataset is necessary to accept the predictive capability of the model. Second, the model utilized deal variables, such as acquisition stake ratio as a linear scale variable, whereas some researchers have demonstrated a non-linear effect of the acquisition stake ratio (Faccio and Masulis 2005). Such non-linear effects could not be implemented in structural equation modeling.

Our M\&A performance model can be enhanced by including other firm-level factors, which were considered in different performance studies in India and China. In this paper we did not study the role of business groups in the acquisition performance of Indian companies. Past empirical studies have demonstrated that affiliation with large business groups provides Indian firms with better access to capital for investments, and thus acts as an antecedent for acquisitive behavior (Lensink et al. 2003). Especially in absence of efficient capital markets, firms affiliated to business groups in emerging economies rely on internal capital markets within their respective business groups when it comes to pursuing M\&A activities (Kim and Song 2017). However, considering the prevalence of business groups in India and other emerging markets, it may be important to study how affiliation to business groups influences the outcomes of such acquisitions and offers opportunities to extend the model discussed in this paper. Another future direction lies 
in the role of quality of due diligence and past acquisition experience in realizing value from acquisitions. Based on a meta-analysis of a large number of M\&A research papers on acquisitions in China, Zhu and Zhu (2016) posited that due diligence is particularly important for Chinese firms to gain value from domestic and cross-border M\&As. Chinese firms, which often lack acquisition and internationalization experience, need to be more careful in target selection because potential targets have incentives to hide negative information and exaggerate positive aspects to increase selling prices. They also observed that government ownership/political advantage of Chinese acquirers is positively related to the performance of Chinese firms' domestic M\&As, and this positive relationship becomes weaker as institutional transition/development in China continues. On the other hand, government ownership/political advantage of Chinese acquirers is negatively related to the performance of Chinese firms' cross-border M\&As, and this negative relationship becomes weaker or turns to be positive as institutional transition/development in China continues. Therefore, an enhanced performance model that includes these factors would further our knowledge of M\&A performance among emerging market firms. This work can also be further extended to consider target firms' operating characteristics and develop a more holistic, predictive performance model.

Summarizing, this paper has tried to answer one of the fundamental questions in M\&A research-how do M\&As create value? While a few M\&A performance studies have been conducted on emerging market firms in the past using multivariate regression, the structural equation model developed here is unique as it considers simultaneous analysis of direct and indirect relationships among the independent and dependent variables, providing a robust insight on antecedents of post-acquisition firm performance, measured from multiple dimensions. Practitioners will find the results useful for decisions on acquisition targets as the results provide insights on how firm-level factors and transaction characteristics moderate various dimensions of firm performance over the short term as well as the long term.

Funding: This research received no external funding.

Data Availability Statement: Data available on request.

Conflicts of Interest: The author declares no conflict of interest.

\section{References}

Ahsan, Faisal Mohammad, Mohammad Fuad, and Ashutosh Kumar Sinha. 2021. Seeking strategic assets within cross-border acquisition waves: A study of Indian firms. Journal of International Management 27: 100875. [CrossRef]

Alexandridis, George, Christos F. Mavrovitis, and Nickolaos G. Travlos. 2012. How have M\&As changed? Evidence from the sixth merger wave. The European Journal of Finance 18: 663-88.

Alexandridis, George, Kathleen P. Fuller, Lars Terhaar, and Nickolaos G. Travlos. 2013. Deal size, acquisition premia and shareholder gains. Journal of Corporate Finance 20: 1-13. [CrossRef]

Alhenawi, Yasser, and Sudha Krishnaswami. 2015. Long-term impact of merger synergies on performance and value. The Quarterly Review of Economics and Finance 58: 93-118. [CrossRef]

André, Paul, Maher Kooli, and Jean-François L'Her. 2004. The Long-Run Performance of Mergers and Acquisitions: Evidence from the Canadian Stock Market. Financial Management 33: 27-43.

Ben-David, Itzhak, Utpal Bhattacharya, and Stacey E. Jacobsen. 2020. Do Acquirer Announcement Returns Reflect Value Creation? (No. w27976). National Bureau of Economic Research. Available online: https:/ / www.nber.org/papers/w27976 (accessed on 15 October 2021).

Bhabra, Harjeet S., and Jiayin Huang. 2013. An empirical investigation of mergers and acquisitions by Chinese listed companies, 1997-2007. Journal of Multinational Financial Management 23: 186-207. [CrossRef]

Bouwman, Christa H., Kathleen Fuller, and Amrita S. Nain. 2009. Market valuation and acquisition quality: Empirical evidence. The Review of Financial Studies 22: 633-79. [CrossRef]

Bower, Joseph. 2001. Not All M\&A's Are Alike-And That Matters. Harvard Business Review 79: 92.

Busija, Edith C., Hugh M. O'Neill, and Carl P. Zeithaml. 1997. Diversification Strategy, Entry Mode, and Performance: Evidence of Choice and Constraints. Strategic Management Journal 18: 321-27. [CrossRef]

Capon, Noel, John U. Farley, and Scott Hoenig. 1990. Determinants of Financial Performance-A Meta-analysis. Management Science 36: 1143-59. [CrossRef]

Capron, Laurence. 1999. The Long-Term Performance of Horizontal Acquisitions. Strategic Management Journal 20: 987-1018. [CrossRef] 
Capron, Laurence, and Nathalie Pistre. 2002. When Do Acquirers Earn Abnormal Returns? Strategic Management Journal 23: 781-94. [CrossRef]

Capron, Laurence, Will Mitchell, and Anand Swaminathan. 2001. Asset Divestiture Following Horizontal Acquisitions: A Dynamic View. Strategic Management Journal 22: 817-44. [CrossRef]

Chidambaran, N. K., Dipali Krishnakumar, and Madhvi Sethi. 2018. Cross-border vs. domestic acquisitions: Evidence from India. Journal of Economics and Business 95: 3-25. [CrossRef]

Cloodt, Myriam, John Hagedoorn, and Hans Van Kranenburg. 2006. Mergers and acquisitions: Their effect on the innovative performance of companies in high-tech industries. Research Policy 35: 642-54. [CrossRef]

Das, Arindam, and Sheeba Kapil. 2015. Inorganic growth of technology sector firms in emerging markets. International Journal of Emerging Markets 10: 52. [CrossRef]

Devos, Erik, Palani Rajan Kadapakkam, and Srinivasan Krishnamurthy. 2009. How do mergers create value? A comparison of taxes, market power, and efficiency improvements as explanations for synergies. The Review of Financial Studies 22: 1179-211. [CrossRef]

Doukas, John A., and L. H. Lang. 2003. Foreign Direct Investment, Diversification and Firm Performance. Journal of International Business Studies 34: 153-72. [CrossRef]

Faccio, Mara, and Ronald W. Masulis. 2005. The choice of payment method in European mergers and acquisitions. The Journal of Finance 60: 1345-88. [CrossRef]

Finkelstein, Sydney, and Jerayr Haleblian. 2002. Understanding Acquisition performance: The role of transfer effects. Organization Science 13: 36-47. [CrossRef]

Fowler, Karen L., and Dennis R. Schmidt. 1989. Determinants of Tender Offer Post-Acquisition Financial Performance. Strategic Management Journal 10: 339-50. [CrossRef]

Francoeur, Claude. 2006. The Long-Run Performance of Cross-Border Mergers and Acquisitions: The Canadian Evidence. Corporate Ownership \& Control 4: 312-23.

Gaur, Ajai S., and Vikas Kumar. 2009. International Diversification, Business Group Affiliation and Firm Performance: Empirical Evidence from India. British Journal of Management 20: 172-86. [CrossRef]

Gerbaud, Ricardo Romero, and Anne S. York. 2007. Stock Market Reactions to Knowledge-Motivated Acquisitions. Advances in Mergers and Acquisitions 6: 127-56. [CrossRef]

Hagedoorn, John, and Geert Duysters. 2002. The Effect of Mergers and Acquisitions on the Technological Performance of Companies in a High-tech Environment. Technology Analysis \& Strategic Management 14: 67-85.

Harford, Jarrad. 1999. Corporate cash reserves and acquisitions. The Journal of Finance 54: 1969-97. [CrossRef]

Hayward, Mathew L. 2002. When Do Firms Learn from Their Acquisition Experience? Evidence from 1990-95. Strategic Management Journal 23: 21-39. [CrossRef]

$\mathrm{Hu}$, Nan, Lu Li, Hui Li, and Xing Wang. 2020. Do mega-mergers create value? The acquisition experience and mega-deal outcomes. Journal of Empirical Finance 55: 119-42. [CrossRef]

IMAA, Institute for Mergers, Acquisitions and Alliances. 2021. M\&A Statistics. Available online: https://imaa-institute.org/mergersand-acquisitions-statistics / (accessed on 16 September 2021).

Kale, Prashant. 2004. Acquisition value creation in emerging markets: An empirical study of acquisitions in India. In Academy of Management Best Paper Proceedings 2004. New Orleans: Academy of Management, pp. H1-H6.

Khanna, Tarun, and Krishna G. Palepu. 2010. Winning in Emerging Markets: A Road Map for Strategy and Execution. Boston: Harvard Business Press.

Kim, Hyejun, and Jaeyong Song. 2017. Filling institutional voids in emerging economies: The impact of capital market development and business groups on M\&A deal abandonment. Journal of International Business Studies 48: 308-23.

King, David R., Dan R. Dalton, Catherine M. Daily, and Jeffrey G. Covin. 2004. Meta-analyses of Post-Acquisition Performance: Indications of Unidentified Moderators. Strategic Management Journal 25: 187-200. [CrossRef]

Kumar, B. Rajesh, and S. Paneerselvam. 2009. Mergers, Acquisitions and Wealth Creation: A Comparative Study in the Indian Context. IIMB Management Review 21: 222-42.

Lebedev, Sergey, Mike W. Peng, En Xie, and Charles E. Stevens. 2015. Mergers and acquisitions in and out of emerging economies. Journal of World Business 50: 651-62. [CrossRef]

Lensink, Robert, Remco Van der Molen, and Shubashis Gangopadhyay. 2003. Business groups, financing constraints and investment: The case of India. The Journal of Development Studies 40: 93-119. [CrossRef]

Lien, Lasses B., and Peter G. Klein. 2006. Relatedness and Acquirer Performance. Advances in Mergers and Acquisitions 5: 9-23.

Lin, Bou-Wen, Yikuan Lee, and Shih-Chang Hung. 2006. R\&D Intensity and Commercialization Orientation Efforts on Financial Performance. Journal of Business Research 59: 679-85.

Lu, Jane W., and Paul W. Beamish. 2004. International Diversification and Firm Performance: The S-Curve Hypothesis. The Academy of Management Journal 47: 598-609.

Lubatkin, Michael. 1987. Merger Strategies and Stockholder Value. Strategic Management Journal 8: 39-53. [CrossRef]

Markides, Constantinos C. 1995. Diversification, Restructuring and Economic Performance. Strategic Management Journal 16: 101-18. [CrossRef]

Meglio, Olimpia, and Annette Risberg. 2011. The (mis) measurement of M\&A performance-A systematic narrative literature review. Scandinavian Journal of Management 27: 418-33. 
Nagano, Mamoru, and Yuan Yuan. 2007. Cross-Border Acquisitions in a Transition Economy: Recent Experiences of China and India. Available online: http:/ / ssrn.com/abstract=1683895 (accessed on 16 September 2021).

Peng, Mike W., Sergey Lebedev, Cristina O. Vlas, Joyce C. Wang, and Jason S. Shay. 2018. The growth of the firm in (and out of) emerging economies. Asia Pacific Journal of Management 35: 829-57. [CrossRef]

Ramaswamy, Kannan. 1997. The Performance Impact of Strategic Similarity in Horizontal Mergers: Evidence from the US Banking Industry. The Academy of Management Journal 40: 697-715.

Reddy, Krishna, Muhammad Qamar, and Noel Yahanpath. 2019. Do mergers and acquisitions create value?: The post-M\&A performance of acquiring firms in China and India. Studies in Economics and Finance 36: 240-64.

Renneboog, Luc, and Cara Vansteenkiste. 2019. Failure and success in mergers and acquisitions. Journal of Corporate Finance 58: 650-99. [CrossRef]

Richard, Pierre J., Timothy M. Devinney, George S. Yip, and Gerry Johnson. 2009. Measuring Organizational Performance as a Dependent Variable: Towards Methodological Best Practice. Journal of Management 35: 718-804. [CrossRef]

Seth, Anju, Kean P. Song, and R. Richardson Pettit. 2002. Value Creation and Destruction in Cross-Border Acquisitions: An Empirical Analysis of Foreign Acquisitions of U.S. Firms. Strategic Management Journal 23: 921-40. [CrossRef]

Simerly, Roy L., and Mingfang Li. 2000. Environmental Dynamism, Capital Structure and Performance: A Theoretical Integration and an Empirical Test. Strategic Management Journal 21: 31-49. [CrossRef]

Tichy, Gunther. 2001. What do we know about success and failure of mergers? Journal of Industry, Competition and Trade 1: 347-94. [CrossRef]

Uhlenbruck, Klaus, and Julio O. Castro. 2000. Foreign Acquisitions in Central and Eastern Europe: Outcomes of Privatization in Transitional Economies. The Academy of Management Journal 43: 381-402.

Vanhaverbeke, Wim, Geert Duysters, and Niels Noorderhaven. 2002. External Technology Sourcing Through Alliances or Acquisitions: An Analysis of the Application-Specific Integrated Circuits Industry. Organization Science 13: 714-33. [CrossRef]

Vilas-Boas, Ricardo, and Isabel Suárez-González. 2007. Internationalization and Firm Performance: The S-Curve Hypothesis under the Eurozone Context. Available online: http:/ / www.eco.uva.es/empresa/uploads/dt_15_07.pdf (accessed on 16 September 2021).

Zhu, Hong, and Qi Zhu. 2016. Mergers and acquisitions by Chinese firms: A review and comparison with other mergers and acquisitions research in the leading journals. Asia Pacific Journal of Management 33: 1107-49. [CrossRef]

Zollo, Maurizio, and Degenhard Meier. 2008. What Is M\&A Performance? Academy of Management Perspectives 22: 55-77. 